\title{
The Effect of CT on HRMS: Case of Automobile Industry in Iran
}

\author{
Mohammad Esmaeil Ansari \\ Department of Management, University of Isfahan, Isfahan, Iran \\ Tel: 98-913-116-1383Ｅ-mail: Ansari@Ase.ui.ac.ir \\ Ali Shaemi \\ Department of Management, University of Isfahan, Isfahan, Iran \\ Tel: 98-913-361-3588Ｅ-mail: Alishaemi@Yahoo.com \\ Ali Atafar \\ Department of Management, University of Isfahan, Isfahan, Iran \\ Tell: 98-913-114-1182Ｅ-mail: Attafar@Yahoo.com \\ Vahid Ghasemi \\ Department of Sociology, University of Isfahan, Isfahan, Iran \\ Tel: 98-913-317-8290Ｅ-mail: V.Ghasemi@Ltr.ui.ac.ir
}

Ali Safari (Corresponding author)

Department of Management, University of Isfahan, Azadi Square, Isfahan, Iran

Tel: 98-913-321-6331_E-mail: A.Safari28@Gmail.com

Received: August 27, 2011

Accepted: October 11, $2011 \quad$ Published: January 16, 2012

doi:10.5539/ijbm.v7n2p58

URL: http://dx.doi.org/10.5539/ijbm.v7n2p58

\begin{abstract}
The objective of this article is to develop a model of core technology (CT) that would effect on one of the most important inter-organizational variables, the human resource management system (HRMS) in automobile industry in Iran. The statistical population consists of all automobile manufacturing plants in Iran and sample size is 4 plants. The data gathering tools consist of two questionnaires. 269 copies were distributed, only $78 \%$ responded that were analyzed in order to test the conceptual model. The structural equations modeling (SEM) and crossover regression analysis have been applied. The major question of this study referring to the effect of CT on HRMS with respect to SEM related indexes and crossover regression analysis had statistical significance when the proposed model evolved.
\end{abstract}

Keywords: Core Technology, Human Resource Management System, Automobile, Iran

\section{Introduction}

In the third millennium, the organizations do not rely on their competitive advantages based on finance and marketing. They find their advantages in the optimized implementation of the strategic resource of the manpower in all their comprehensive planning. This approach forces the organizations to seek foolproof human resource management systems (HRMS) in harmony with and observance of the system orientation with other constituent managements in the overall system. No organization can function without harmony that exists through precisely designed system throughout if the objective is long-term; therefore, for an effective set up the standpoint of the organization should be system oriented.

One of the components in an organization that affect the HRMS is core technology (CT). Aspect in a sense that the administrators and authorities of HRMS count on CT and seek to coordinate these two vital elements in planning and implementation. According to the conducted studies in this area through Harpaz and 
Meshoulam(2010), Bernardin(2010), Anagnostopoulos and Sioutis(2010), Cronin et al(2006), Balon and Trkman(2003) and other studies in this field, the HRMS and CT are in interaction and CT has its impact on HRMS to a point that each type of CT can have a specific effect on HRMS. This is the reason that different organizations with different CTs have different HRMS set ups (Harpaz and Meshoulam, 2010). In this study, while investigating the samples' conceptual framework to be proposed for CT effect on HRMS and reviewing the previous studies conducted in this area, finding the answer to the following question is initiated: Does CT effect HRMS in automobile industry of Iran?.In order to find an answer in this article, first the effect of CT on HRMS is studied in the literature review. Next the conceptual framework for this presentation accompanied with the applied methodology will be presented. Then the addressed question will be evaluated and finally the proposed effect of CT on HRMS will conclude the article.

\section{Literature Review}

\subsection{Human Resource Management System (HRMS)}

Ivancevich (2010) acknowledges HRMS as a system directly related to human beings in organizations that facilitate the effective application of their power to attain individual and common organizational objectives. Armstrong (2006) refers to HRMS as a coherent and strategic viewpoint that is the most valuable asset in an organization the human beings who try to materialize the individual and common objectives in the organization. According to these two definition and what Storey(1992), Dessler(2008), Cassio(2010) and Bernardin(2010) had to say in this respect, it could be understood that the HRMS is defined as a system and subsystems that are drown together to manage a strategic organizational resource called the "organizational human" with respect to the long-term objectives. Organizations try to apply the accurate managing human resource in competition area and generate more added values against other organizations.

Many models have been proposed on HRMS and many researchers have regarded different subsystems for HRMS.A few of these important models are presented in table 1. (Refer to notes)

Since the presented models in this field are numerous and various, in this study the attempt is made to extract a model from the combination of the content of table one. Therefore, a model with seven subsystems recruitment and selection(Dessler, 2008; Cassio, 2010; Ivancevich, 2010; Fombrun et al,1984; Beer et al, 1984; Gest, 1997; Bernardin and Russel, 1993; Singer, 1990), training (Dessler, 2008; Cassio, 2010; Ivancevich, 2010; Baldrige, 2003; Gest, 1997; Singer, 1990), payment(Dessler, 2008; Cassio, 2010; Ivancevich, 2010; Singer, 1990), reward(Dessler, 2008; Cassio, 2010; Ivancevich, 2010; Fombrun et al,1984; Beer et al, 1984; Gest, 1997; Hendry and Pettigrew, 1990; Bernardin and Russel, 1993; Singer, 1990), performance appraisal(Dessler, 2008; Cassio, 2010; Ivancevich, 2010; Fombrun et al,1984; Gest, 1997; Bernardin and Russel, 1993) and human resource work relations(Dessler, 2008; Cassio, 2010; Ivancevich, 2010; Baldrige, 2003; Hendry and Pettigrew, 1990; Bernardin and Russel, 1993; Singer, 1990) have their derivatives for presentation of a more accurate perspective of HRMS composition. This issue is illustrated in figure 1. (Refer to notes)

These derivations of the subsystems will be considered as identification index for the addressed questions in the questionnaire.

\subsection{Technology and Core Technology (CT)}

Technology is a complex concept. Some conceive it as information technology (IT) and elaborate on it to a point where it becomes a synonym for technology. Jones and Gorge (2003) described technology as being a combination of skills, knowledge, tools, equipment, computers and the facilities that are known to be applied for design, production and distribution of products and providing services. Hatch (2006) defines technology, as the tool of approaching the desired advance or a desired output that is conceptualized in products format or service provided. With an accurate deliberation on the presented definitions regarding technology it can be deduced that almost in all definitions the presence of physical object, human performance, scientific and practical knowledge is inevitable. All these factors establish the bases of the pronounced technology although different viewpoints exist in this respect (Lee et al, 2009).Based on an outside view, a common believe among the economists, technology is a tool through which the society provides for food, residence, bank loans, medical care, public education, etc. This viewpoint is the same black box concept of technology that shows the environmental level of the related analysis. But by looking inside the organization and focusing on the real manner of its conducts that is relying on the methods and knowledge that are manmade the conception of technology becomes clear. This is the organizational level conception of technology that is emerged from the realm of research, engineering and manufacturing. In addition to the environmental and organizational level of analysis of technology, the concept of technology can be applied in some other sub-levels such as unit and task level conception of technology (Hatch 2006). 
Due to the complexities at different levels of technology applied in an organization, so many studies have been conducted in order to simplify and unify the conceptions CT (organizational level conception of technology) (Seppanen et al, 2010; lee et al, 2009).The organizational CT is the type of technology that incorporates the production process in order to present the main product and the organizational services to the consumer. This type of technology that is subject to organizational viewpoint usually is adopted by one of the departments in the organization and in order to show the technology as a whole in the organization and prevent ambiguities due to the available different levels it is referred to as the main or the core technology (CT). Examples of this fact are the technologies applied in a steel and automobile manufacturing plants that uses that specific steel and automobile (Vanhaverbeke et al 2009). In this research, in order to prevent complexities and ambiguities caused by different levels of technology, the type view point and the attempts made to identify and analyze its effect on the HRMS in the plants under study, the organizational focus here is on CT.

Through the assessment of the related literature, five typologies are identified by Joan Woodward (1958), James Tompson (1967), Edward Harvey (1968), Charls Perrow (1967) and Stephan Robbins (1998). The types of these typologies, their advantages and disadvantages are presented in table 2. (Refer to notes)

With respect to the presented typologies in organizational CT, due to the expanded spectrum of CT as a result of Perrows typology framework that is applied in service and production organizations and is approved by Magnusen(1970), Hage and Aiken (1969),Van de Ven and Dolbecq (1974), Moh(1971), Daft and Mecintosh(1981), Barnes(2006), Kallinikos(2005) and Leonardi and Barley (2008) are credited by organizations . For the purposes of this study, this framework is applied. This framework is presented base on the two variable dimensions of task variability and task analyzability. Task variability is defined based on the number of exceptions that we face in the standard manners of adopting a specific technology; task analyzability indicates the limits of available analytical methods with respect to the identification of exceptions faced by the management (Perrow, 1967; Daft, 2007). Based on these two dimensions a four-part matrix of the CT is presented in figure 2. (Refer to notes)

In this figure, Perrow's typology consists of routine, craft, engineering and non-routine technologies. In the mentioned advantages of this type of typology, Perrow's format provides the bases for identification and evaluation of the effect of CT on HRMS in this study.

\subsection{The effect of CT on HRMS}

In its nature, the CT as an inter-organizational factor has its effect on HRMS and any change in CT changes the HRMS necessarily (Khalil, 2000).After a thorough review it becomes evident that the effect expansion of HRMS is two;

\subsubsection{Operational effect}

This effect is the result of applying the non-core-technology such as computers, devices etc. as tools in human resources management. This type of application is in a significant growth and is considered on vital factor in decision making process regarding human resources such as planning, recruitment, selection, training and performance management (Chapman and Webster, 2003). With the expansion of computer industry and internet in the recent years and its application and the effect on human resources technology in the fields of human resource evaluation, selection, their records evaluation, running interviews with the staff, staff duties, staff control, human resource management motivations and information and promotion of it in organization have been highlighted (Balon and Trkman , 2003; Bartram, 2000).According to Balon and Tarkman (2003), the internet is very effective in indication of How? Why? Where? and When do the human resources get to work?

\subsubsection{The strategic and procedural effect}

The technology in addition to being a tool in HRM, does effect the strategic procedural aspect of the same (Khalil, 2000; Cronin et al, 2006; Wallace, 2004; Matsui, 2002; McCole et al 2001; Sagie and Weisberg, 2001).One of the strategic aspects of this effect is the recruitment and selection, because human resource management could be adopted only through skilled and knowledgeable staff for optimized CT performance (Pe'rez et al, 2002; Lepak and Snell, 1998 ;Balon and trkman 2003; and Woods, 1999).CT has its effect on training aspect of HRM in a sense that it calls for a review of the organizational objectives. Training is accompanied with advances in CT will result in developing the desired skill and knowledge among the staff (Khalil, 2000; Cronin et al, 2006; Wallace, 2004 and Matsui, 2002). Payment is effected by CT .CT determines the level of mental and physical contribution of the staff in the organization according to which their salaries are fixed and paid (Harel and Tzafrir, 2001; Sagie and Weisberg, 2001). The element of reward in HRMS should be in harmony with CT that encourages the efficiency of the outcome by the staff at different levels and creates enthusiasm (Harel and Tzafrir, 2001).Performance appraisal and work relations that are affected by CT and bring about close relation between management and the staff and kind of shapes the overall operational 
structure(Pe'rez et al , 2002; Vermens and Weldhone , 2006).After all the procedural and strategies effects of CT on HRMS considered in this research the sole question is formed as:

\section{Does CT have an effect on HRMS in automobile industry of Iran?}

According to figure 1, with respect to Perrow's format as the basis of CT identification with its procedural process that effects the addressed question is developed in Figure 3. When analyzing figure 3 it can be deduced that $\mathrm{CT}$ in automobile industry of Iran is identified through the two dimensions addressed in Perrow's typology and then all other sub-systems of HRMS in this industry are evaluated and tested for their statistical significance in order to extract the final model in this respect. (Refer to notes)

\subsection{Implications of the study}

Globalization, the potential of knowledge and technology sharing, the down-sizing and agility of the organization in addition to the rapid evaluation in technology exert their influence on the developing countries like Iran. The administrators in such countries are obligated to prepare new necessary infrastructure in software and hardware forms. The hardware portion of the infrastructure could be easily achieved through physical changes. The software portions of the infrastructure take more time and effort that end up in managerial system changes. The HRMS is one subjected to the second if the harmony in technology and management system is to be accomplished. Therefore, the outcomes of this study that is the presentation of a model where the CT have its influence on the managerial systems regarding HRMS in automobile industry in Iran, contributing not only to the exact diagnosis of HRMS but its sub-systems as well. Through this approach it becomes clear that which section of the HRMS has been subject to high or low influence through the organizational CT.

Moreover, based on the twenty year national economical forecast where the privatization has to increase and the government control has to decrease, the technical changes and competitions that wait for all Iranian organizations is inevitable. The findings of this study would contribute to establish a comprehensive prospective view based on principles in order to prevent economical depression and handicap by implementing the necessary changes in HRMS to become sustainable through long-term planning. This procedure will keep the economic advance in balance and would make the unaware organizations to follow the automobile industry practice on the 20 year path nationwide.

The policy making in Iran regarding technology cannot be without the above mentioned considerations. The policies would not become materialized if they are not objective oriented based on pre planning. Awareness in how the changes in HRMS would affect the automobile industry would contribute to a better policy making with a wider and more comprehensive view that in it would lead to accuracy in economical planning and advances.

\subsection{The conducted studies}

Baran et al (2002) conducted a study on the effect of the newly developed CT on different companies in Turkey. Here the result show that $\mathrm{CT}$ has low statistical significant on HRMS in variety of Turkish industries.

Matsui (2002) conducted similar study on 64 plants in Japan, Germany, Italy, England and the USA. Here the results indicate that the CT really affects HRM and improves the training, manpower conduct, decision making process and resolving HRM managerial problems.

Cronin et al (2006) conducted the same study on a very big scale of HRMS in U.S government through the effect of CT on HRMS .The results indicate that the sub-systems: work relations, training, recruitment and performance appraisal are effected and this is evident in the differences observed in comparison with the periods before adopting CT.

Burke and $\mathrm{Ng}$ (2006) as a result of their study conducted on Canadian companies found that $\mathrm{CT}$ as an essential variable has affected the staff skills, HR communications and the nature of the business.

Jackson and Sloane (2007) conducted a research on determining the effect of CT on the following four factors: HRMS, organizational culture, organizational procedures and management style. The results showed that the four factors had been affected by CT, except the sub-system HR in a specific manner.

Maguire and Redman (2007) in their research tried to determine the effect of HRMS by deploying information systems as a new CT for the public service oriented organization in England. The results indicate that lack of effectiveness and non-preparedness in some elements of the HRMS caused the failure of the newly introduced CT accompanied with information system. They concluded that with the advent of the newly developed CT, preparation of the sub-systems like training, reward and payment are necessary.

\section{Methodology}

The library study method related text reviews and field studies questionnaires are applied in this work with the objective to identify the CT type, HRMS and the effect of CT on HRMS. This study is of an analytic, descriptive survey nature from field studies branch. 


\subsection{Sampling}

The statistical populations in this study are composed of all automobile manufacturing plants of Iran. The sampling method adopted here is the categorical sampling fit to the capacity. By distributing the initial questionnaires and using Cochran formula 4 plants are selected as samples for evaluation. Based on the calculated sample capacity and specified numbers to each category, the plants that were selected randomly are: Iran Khodro, Saipa, Diyar Khodro and Zagros Khodro plants.

\subsection{Data collection}

The tools of data collection here are two questionnaires. The first questionnaire is related to HRMS and evaluation of its sub-systems with 71 items. This questionnaire has validity that is acknowledged by $10 \mathrm{HRM}$ experts in addition to the verification through confirmatory factor analysis. The reliability of this questionnaire is calculated through Cronbach with 0.87accuracy. The first questionnaire is distributed among the managers, supervisions and the HRMS staff in the selected plants. The second questionnaire is designed in accordance with the standard (for identifying the style of CT based on Perrow's format) by Withey et al (1983) that includes 10 items to be filled by CT specialists of the selected plants as people of knowledge who are aware of CT. This questionnaire has validity as well and is verified by confirmatory factor analysis. The reliability of the questionnaire is calculated through Cronbach with 0.91. Total of the 269 questionnaires were distributed and 210 (78\%) of which was responded upon for analysis. Data collection process commenced at the beginning of January and finished in the middle of April 2011.

\subsection{Analysing methods}

For data analysis and evaluation of the core question of this study the one sample $t$ test is applied to determine the dimensions of sub HRMS. Structural equation modeling (SEM) analysis was applied through software Amos 18 in order to determine the level of effect of each dimension of CT on HRMS and crossover regression analysis was applied by software Eviews 7 in order to determine the dimension of CT's combined effect on the sub-systems of HRMS.

\section{Result}

Based on the above findings, the only question addressed in this research is being evaluated. The generated data from the first set of questionnaires, the accuracy of the HRMS's dimensions are evaluated. According to table 3, by addressing a question about four possible methods of internal and six methods of external staff recruitment expressed in the questionnaire and conducting the one sample $t$ test, it is revealed that the automobile manufacturing plants apply the promotion-transfer system for internal and walk-ins for external recruitment, this is to illustrate an example. Hence, this approach is regarded as an accurate dimension for recruitment sub system and the data are applied in modeling the structural equations and the crossover regression manner. This is a vivid sample. In order to determine the accurate dimension of all sub-systems the above pattern is followed, the results are expressed in table 3. (Refer to notes)

The following descriptions are extracted from table (3) with respect the sub-systems of HRMS:

Recruitment: is accomplished through promotion-transfer and walk-ins

Selection: is accomplished through personality test, group and non-structured interview with respect to past experiences. It should be mentioned here that the immediate supervisors and the HR manager are the final decision makers

Training: is accomplished through audiovisual and on-the-job training

Payment: is accomplished on variable pay for performance (PFP)

Rewards: is financial based on gain sharing bonuses, non-financial bases training pay like management sciences, foreign languages, computer etc. Due to non-significance aspect of the flexible reward system, it is almost non-applicable

Performance appraisal: the immediate supervisor in charge controls the performance results

Work relations: depends on the collective bargaining by the staff and HR managers

After defining the essentials of HRMS in automobile manufacturing plants, according to table (3), the results obtained from the second questionnaire regarding the measuring of the two task variability and analyzability concepts are evaluated. Lack of possibility in merging these two dimensions in modeling the structural equations due to the difference in the nature of each dimension and with due respect to the effect of each dimension of CT on sub-HRMS, the dimensions effect are evaluated separately. Amos 18 is applied in calculating the CT's dimensions structural equations that affect the sub-HRMS's in automobile plants. 
The abbreviations in Figure 4 are defined as follows:

Task Variability(TV), Task Analyzability(TA), Promotion-Transfer(P), Walk-Ins(WI), Personality Test(PT), Group Interview(GI), Non-Structured Interview(NSI), Past Experiences(PE), Immediate Supervisors and HR Managers' decision making(ISM), Audiovisual method(A), On-the-Job method(OJ), Variable pay for performance pay (PI, P2, P3), Financial Reward(FR), Non-Financial Reward (NFR), Evaluation by Supervisors(SE), Result Evaluation regarding performance(RE), Collective Bargaining(BI, B2).

The CMIN/DF, P-Value, RMSEA, TLI, PCFI indexes at the bottom of figure 4 indicates the desirability and the significance of all calculated regression weights. Here it can be deduced that this method has statistical significance and the same is true for all CT's dimensions on sub-HRMS's in all automobile plants. Table 4 indicates goodness of fit indexes for the structural equation model. (Refer to notes)

After the CT's dimensions effect on the sub-HRMS's is achieved, the combined effect of the two dimensions of $\mathrm{TV}$ and TA are tested for the same purpose mentioned above by applying the crossover regression and the General Least Squares (GLS)method where(due to the non-uniformity of variances during crossover regression test) Eviews 7 is applied. The outcome of conducted crossover regression test is presented in table 5. (Refer to notes) According to table 5 there exists a positive significance effect on the sub-HRMS of automobile manufacturing plants.

The selected typology in this study ended up in determining a 7 point spectrum measuring system being applied in $\mathrm{CT}$ in the automobile manufacturing plants as shown in Figure 5. (Refer to notes)

Therefore, based on Perrow's typology, the types of CT applied in automobile manufacturing plants that are of routine technology nature are studied.

\section{Conclusion}

Based on the data analysis obtained from the questionnaires and adopting proper statistical tests an answer could be provided for the sole question addressed in this study: the CT applied in the automobile manufacturing plants in Iran does affect the HRMS in a positive and significant manner. Hence, based on the conceptual formwork and assessment of the addressed question, figure 6 is being presented. (Refer to notes)

According to Figure 6 our findings with respect to categorization of the automobile industry that are CT and routine technology oriented correspond to that of the Daft(2007).CT, among many intra-extra organizational factors that affect HRMS as an inter-organizational factor, are recognized and practiced through automobile industry of Iran.

This factor contributes to the internal recruitment sub-system through promotion and transfer method and walk-ins for external recruitment at a 0.071 level of effect. This finding corresponds to that of the Cronin et al (2006), Pe'rez et al(2002), Lepak and snell(1998), Balon and Trkman(2005) and Woods(1999). The CT coefficient in constituting the sub-systems in the automobile industry is 0.092 regarding the effect selection through personality tests, non-structured group interviews by evaluating past experiences and drawing the final decision by the immediate supervisor accompanied with the HR manager. This coefficient of effect corresponds with that of the Maguire and Redman (2007), Cronin et al(2006), Burke and $\mathrm{Ng}(2006)$, Wallace(2004), Matsui(2002). The effect level for

sub-system of training is 0.124 , a result of audiovisual and on-the-job training. Regarding the effect of CT on training, the result obtained from the studies conducted by Cronin et al(2006), Burke and $\operatorname{Ng}(2006)$, Wallace(2004), Matsui(2002) and Maguire and Redman(2007) are in agreement with the result of this study. For sub-system of payment the obtained 0.135 level is in harmony with the findings of Maguire and Redman (2007),Harel and Tzafrir (2001), Sagie and Weisberg(2001). This fact is directly related to the CT effect on payment sub-system that ends in pay for performance (PFP) pay. As for sub-system reward the CT effect level is 0.062. Here we have a reward system where the financial reward is the gain sharing bonus and non-financial reward is the training pay bonus. The finding here corresponding to the findings of Harel and Tzafrir(2001), Maguire and Redman(2007). Performance appraisal has 0.113 level of effect that is similar to the findings of Cronin et al (2006), Pe'rez et al (2002). In this sub-system the performance appraisal is directly evaluated by the immediate supervisor. This evaluation is based on the related performance result. And finally, the work relations with 0.097 efficiency level based on the collective bargaining is extracted from this study that fits well with the findings of Voermans and Veldhoven(2006), Cronin et all (2006), Pe'rez et al (2002).

The general conclusion of this study is based on numerous intra-extra organizational factors affecting the HRMS in the automobile industry of Iran. The core-routine technology is identified as an influential factor on HRMS in a positive and significance sense in the automobile industry of Iran. 


\section{Limitations of the study}

Similar to all other studies conducted in the sciences of humanities here the prevailing restrictions are described as follows:

1-Lack of studies in the field of the CT on HRMS regarding organizations worldwide in Iran; hence, not enough recorded findings to compare the findings of this study with.2-By studying the related available literature it was revealed that the there exist numerous internal and external organizational factors that influence the HRMS; therefore evaluation of all affective variables in parallel with organizational CT in a comprehensive model is impossible due to the determined time.3-Due to the evaluation of automobile manufacturing industry, generalization of the finding in this study regarding other industries is not proper.4-Considering one combined HRMS based on the available overlapping elements among between the models regarding the numerous variables with respect to HRMS measurement, led to developing a multi dimensional questionnaire with many items that has been time consuming and in some cases preventing the subjects to provide complete answers due to lack of concern in accuracy in response. 5-Appling the conceptions and mental perceptions of the respondents, despite the apparent HRMS and applied CT in organization, could lead to restrictions in the content of the answers.

\section{Future research directions}

Based on the theoretical studies and empirical cases that this researcher has encountered with during this work, the following topics or ideas could be of interest for other researchers in this field.

1) The effect of other internal organizational factors such as the organizational culture, management style and strategy on HRMS

2) The effect of CT on HRMS among service and industrial organization based on the developed framework introduced by expert like Woodward and Tompson

3) The effect of CT on internal organizational variables like organizational structure and culture among selected organizations

4) Evaluation of moderation role regarding the variables like organizational improvement and maturity with due respect to CT influence on HRMS

5) Evaluating the necessities in the HRM field in order to overhaul the existing CT

6) Evaluating the influence of IT on HRMS in organizations

7) Testing this proposed method on other service oriented and industrial organizations

\section{References}

Anagnostopoulos, K. P., \& Sioutis, P. (2010). The Technology-Production Base of the Firm: Creating Sustainable Strategic Competitive Advantage. The International Journal of Knowledge, Culture and Change Management, 10(1), 333-347.

Armstrong, M. (2006). Human Resource Management Practice. (10 ${ }^{\text {th }}$ ed.), London: Cambridge University Press.

Balon, P., \& Trkman, P. (2003). Influence of Internet and Information Technology on Work and Human Resource Management. Material published as part of these proceedings of Informing Science.

Baran, M., Karabulut, E., Semercioz, F., \& Pekdemir, I. (2002). The new HR practices in changing organizations: An empirical study in Turkey. Journal of European Industrial Training, 26(2-4), 81-87. http://dx.doi.org/10.1108/03090590210421950

Barnes, J. K. (2006). The Relationship between Perceived Organization Structure and Perceived Technology and Individual Psychological and Group Empowerment. A dissertation submitted in partial fulfillment of the requirements for the degree of Doctor of Philosophy in Business Management, University of Albany: New York.

Bartram, D. (2000). Internet recruitment and selection: Kissing frogs to find princes. International Journal of Selection and Assessment, 8, 261-274. http://dx.doi.org/10.1111/1468-2389.00155

Beer, M., Spector, B., \& Lawrence, P.R. (1984). Managing Human Assets. New York: Fress Press.

Bernardin, H, J. (2010). Human Resource Management: an Experiential Approach. (5 ${ }^{\text {th }}$ ed.). New York: McGraw-Hill.

Bernardin, H, J., \& Russel, E. A. (1993). Human Resource Management: An Experiential Approach. New York: McGrow-Hill, Inc. 
Burke, J. R., \& Ng, E. (2006). The Changing Nature of Work and Organizations: Implications for Human Resource Management. Human Resource Management Review, (16), 86-94. http://dx.doi.org/10.1016/j.hrmr.2006.03.006

Cassio, F.W. (2010). Managing Human Resource: Productivity, Quality of Work Life, Profit. ( ${ }^{\text {th }}$ ed.). New York: McGraw-Hill.

Chapman, D. S., \& Webster, J. (2003).The use of technologies in the recruiting, screening and selection processes for job candidates. International Journal of selection and assessment, 11, 113-119. http://dx.doi.org/10.1111/1468-2389.00234

Cronin, B., Morath, R., Curtin, P., \& Heil, M. (2006). Public sector use of technology in managing human resources. Human Resource Management Review, 16, 416-430. http://dx.doi.org/10.1016/j.hrmr.2006.05.008

Daft, L. R. (2007). Organization theory and design. ( $9^{\text {th }}$ ed.). Mason, OH: Thomson South-Western.

Daft, R. L., \& Macintosh, N. B. (1981). A tentation exploration in to amount and equivocality of information processing in organizational work units. Administrative Science Quarterly, 26, 207-224. http://dx.doi.org/10.2307/2392469

Dessler, G. (2008). Human Resource Management. (11 ${ }^{\text {th }}$ ed.). New York: Printic- Hall.

Fombrun, C., Tichy, N. M., \& Devanna, M. A. (1984). Strategic Human Resource Management. New York: Wiley.

Gest, D. (1997). Human Resource Management and Performance: A Review and Research Agenda. The International Journal of Human Resource Management, 8(3), 263-276. http://dx.doi.org/10.1080/095851997341630

Hage, J., \& Aiken, M. (1969). Routine technology, social structure and organizational goals. Administrative Science Quarterly, 366-377. http://dx.doi.org/10.2307/2391132

Harel, H. H., \& Tzafrir, S. S. (2001). HRM practices in the public and private sectors: differences and similarities. Public Administration Quarterly, 25(3), 316-355.

Harpaz, I., \& Meshoulam, I. (2010). The meaning of work, employment relations, and strategic human resources management in Israel. Human Resource Management Review, 20, 212-223. http://dx.doi.org/10.1016/j.hrmr.2009.08.009

Harvey. E. (1968). Technology and the structure of organizations. American Sociological Review, 45, 247-259. http://dx.doi.org/10.2307/2092391

Hatch, J. M. (2006). Organization theory: modern, symbolic and postmodern perspectives. London: Oxford University.

Hendry, C., \& Pettigrew, A. (1990). Human resource management: an agenda for the 1990s. International Journal of Human Resource Management, 1(1), 17-44. http://dx.doi.org/10.1080/09585199000000038

Ivancevich, M., J. (2010). Human Resource Management. (11 $1^{\text {th }}$ ed.), New York: McGraw-Hill.

Jackson, M., \& Sloane, A. (2007). A model for analysing the success of adopting new technologies focusing on electronic commerce. Business Process Management Journal, 13(1), 121-138. http://dx.doi.org/10.1108/14637150710721168

Jones, R. G., \& Gorge, M. J. (2003). Contemporary Management. New York: McGraw-Hill.

Kallinikos, J. (2005). The order of technology: Complexity and control in a connected world. Information and Organization, 15, 185-202. http://dx.doi.org/10.1016/j.infoandorg.2005.02.001

Khalil, M. T. (2000). Management of technology: the key to competitiveness and wealth creation. Boston: McGraw-Hill.

Lee, H., Kim, C., Cho, H., \& Park, Y. (2009). An ANP-based technology network for identification of core technologies: A case of telecommunication technologies. Expert Systems with Applications, 36, 894-908. http://dx.doi.org/10.1016/j.eswa.2007.10.026

Leonardi, M. P., \& Barley, R. S. (2008). Materiality and change: Challenges to building better theory about technology and organizing. Information and Organization, 18, 159-176. http://dx.doi.org/10.1016/j.infoandorg.2008.03.001

Lepak, P, D., \& Snell, A, S. (1998). Virtual HR: Strategic Human Resource Management in the 21st Century. Human Resource Management Review, 8(3), 215-234. http://dx.doi.org/10.1016/S1053-4822(98)90003-1 
Magnusen, K. (1970). Technology and Organizational Differentiation: A Field Study of Manufacturing Corporations. A dissertation submitted in partial fulfillment of the requirements for the degree of Doctor of Philosophy in Business Management, University of Wisconsin: Madison.

Maguire, S., \& Redman, T. (2007). The role of human resource management in information systems development. Management Decision, 45(2), 252-264. http://dx.doi.org/10.1108/00251740710727278

Matsui, Y. (2002). Contribution of manufacturing departments to technology development: An empirical analysis for machinery, electrical and electronics, and automobile plants in Japan. International Journal of Production Economics, 80, 185-197. http://dx.doi.org/10.1016/S0925-5273(02)00317-1

McCole, P., Morrow, T., Ponsonby, S., \& Kelly, B. (2001). The potential training impact of technology on SMEs in Northern Ireland. Journal of European Industrial Training, 2/3/4(25), 90-97.

Moh, L. B. (1971). Organizational technology and organizational structure. Administrative Science Quarterly, 16(4), 444-459. http://dx.doi.org/10.2307/2391764

Pe'rez, P. M., Sa'nchez, M, A., \& de Luis Carnicer, P, M. (2002). Benefits and barriers of telework: perception differences of human resources managers according to company's operations strategy. Technovation, 22, 775-783.

Perrow, C. (1967). A Framework for the Comparative Analysis of Organizations. American Sociological Review, 32(2), 194-208. http://dx.doi.org/10.2307/2091811

Sagie, A., \& Weisberg, J. (2001). The transformation in human resource management in Israel. International Journal of Manpower, 3(22), 226-234. http://dx.doi.org/10.1108/01437720110398275

Seppanen, M., Makinen, S., \& Torkkeli, M. (2010). Evaluating non-core technologies: Contrasting external and internal views on corporate research results. Journal of High Technology Management Research, 21(2), 79-86. http://dx.doi.org/10.1016/j.hitech.2010.02.009

Singer, M, G. (1990). Human Resource Management. New York: PWS-KENT Publishing Co.

Storey, J. (1992). From Personnel Management to Human Resource Management. In Storey, J (ed) New Perspectives on Human Resource Management, London: Routledge.

Tompson, J. D. (1967). Organization in Action. New York: McGraw-Hill.

Van de Ven, H, A., \& Dolbecq, L, A. (1974). A task contingent model of work unit structure. Administrative Science Quarterly, 183-197. http://dx.doi.org/10.2307/2393888

Vanhaverbeke, Gilsing, V., Beerkens, B., \& Duysters, G. (2009). The Role of Alliance Network Redundancy in the Creation of Core and Non-core Technologies. Journal of Management Studies, 46(2), 215-244. http://dx.doi.org/10.1111/j.1467-6486.2008.00801.x

Voermans, M., \& Van Veldhoven, M. (2006). Attitude towards E-HRM: an empirical study at Philips. Personnel Review, 36(6), 887-902. http://dx.doi.org/10.1108/00483480710822418

Wallace, P. (2004). The Internet in the Workplace: How New Technology is Transforming Work. New York: Cambridge University Press.

Withey, M., Daft, L, R., \& Cooper, C, W. (1983). Measure of Perrow's technology: An empirical assessment and a new scale. Academy of management journal, 25, 45-63. http://dx.doi.org/10.2307/256134

Woods, H. R. (1999). Predicting is difficult, especially about the future: human resources in the new millennium. Hospitality Management, 18, 443-456. http://dx.doi.org/10.1016/S0278-4319(99)00048-1

Woodward, J. (1958). Management and Technology. London: Tavistock Institute.

Zwerman, W. (1970). New Perspectives of Organization Theory. Westport Conn: Greenwood Publishing. 
Table 1. Important models proposed for HRMS

\begin{tabular}{|c|c|c|c|c|}
\hline No & Model title & By & Year & HRMS subsystems \\
\hline 1 & Adjustment & $\begin{array}{l}\text { Fombrun, Tichy and } \\
\text { Devanna }\end{array}$ & 1984 & Select, Training, Performance Appraisal, Reward \\
\hline 2 & Harvard & $\begin{array}{l}\text { Beer, Spector \& } \\
\quad \text { Lawrence }\end{array}$ & 1989 & Select, Reward, Work Relations, Human Resources Flow \\
\hline 3 & Singer & Singer & 1990 & $\begin{array}{l}\text { Select, Training, Payment, Reward, Work Relations, Human } \\
\text { Resources Planning, Health \& Safety }\end{array}$ \\
\hline 4 & Warwick & Hendry \&Pettigrew & 1990 & HR Flow, work Systems, Reward, Work Relations. \\
\hline 5 & Storey & Storey & 1992 & $\begin{array}{c}\text { Communications, Job Design, Conflict Management, } \\
\text { Training }\end{array}$ \\
\hline 6 & Bernardin & Bernardin \&Russell & 1993 & $\begin{array}{c}\text { Recruitment and Selection, Communications, Performance } \\
\text { Appraisal, Organizational Designing, Reward, Payment, } \\
\text { Training \& development }\end{array}$ \\
\hline 7 & Gest & Gest & 1997 & $\begin{array}{c}\text { Select, Training, Performance Appraisal, Reward, Job } \\
\text { Analysis, Security }\end{array}$ \\
\hline 8 & Baldrige & Baldrige & 2003 & $\begin{array}{l}\text { Work System, Learning and Training, welfare and } \\
\text { Satisfaction }\end{array}$ \\
\hline 9 & Dessler & Dessler & 2008 & $\begin{array}{c}\text { HR Planning, Recruitment and Selection, Training, } \\
\text { Performance Appraisal, Reward, Work Relations, Health \& } \\
\text { Safety }\end{array}$ \\
\hline 10 & Cassio & Cassio & 2010 & $\begin{array}{c}\text { HR Planning, Recruitment and Selection, Payment, } \\
\text { Performance Management, Health \& Safety Promotion, } \\
\text { Punishment and Discipline }\end{array}$ \\
\hline 11 & Ivancevich & Ivancevich & 2010 & $\begin{array}{c}\text { HR Planning, Recruitment and Selection, Training, } \\
\text { Payment, Reward, Performance Appraisal, Work Relations }\end{array}$ \\
\hline
\end{tabular}

Table 2. The types of typology presented regarding CT

\begin{tabular}{|c|c|c|c|}
\hline Typology & Types of CT & Advantages & Disadvantages \\
\hline Woodward & $\begin{array}{l}\text { Small Batches, Large } \\
\text { Batches and } \\
\text { Continuous-processing } \\
\text { Technology }\end{array}$ & $\begin{array}{c}\text { Approved by Harvey’s } \\
\text { (1968) and Zwerman (1970) } \\
\text { studies }\end{array}$ & $\begin{array}{l}\text { Relying on observations and interviews } \\
\text { Lack of evaluation in big organizations } \\
\text { Not applicable in services organizations }\end{array}$ \\
\hline Tompson & $\begin{array}{l}\text { Long - Linked, Mediation } \\
\text { and Intensive Technology }\end{array}$ & $\begin{array}{l}\text { Applicable in service and } \\
\text { production organizations }\end{array}$ & $\begin{array}{l}\text { No research conducted and ambiguity in its } \\
\text { credibly }\end{array}$ \\
\hline Harvey & $\begin{array}{l}\text { Extra Moderate and Specific } \\
\text { Technical Complexity }\end{array}$ & $\begin{array}{l}\text { Based on Woodward's } \\
\text { typology }\end{array}$ & $\begin{array}{l}\text { Note approved by studies } \\
\text { Not applicable in organizational services }\end{array}$ \\
\hline Perrow & $\begin{array}{c}\text { Routine, Craft, Engineering } \\
\text { and Non- Routine } \\
\text { Technology }\end{array}$ & $\begin{array}{l}\text { Approved by various } \\
\text { researches, } \\
\text { Applicable in service and } \\
\text { production organizations, } \\
\text { Providing an expanded } \\
\text { spectrum for identification }\end{array}$ & $\begin{array}{l}\text { Applying two dimension for dividing the } \\
\text { technology }\end{array}$ \\
\hline Robbins & $\begin{array}{c}\text { Routine } \\
\text { Non-routine }\end{array}$ & $\begin{array}{l}\text { Categorizing other types of } \\
\text { typologies in two dimensions }\end{array}$ & Not approved by the researches \\
\hline
\end{tabular}


Table 3. The results of one sample $t$ test regarding the accurate dimension determination of the sub-HRMS

\begin{tabular}{|c|c|c|c|c|c|}
\hline Variable & Sub-HRMS & Part & Method & t Statistics & Sig \\
\hline \multirow{16}{*}{$\begin{array}{c}\text { Human } \\
\text { Resource } \\
\text { Management } \\
\text { System(HRMS) }\end{array}$} & \multirow{2}{*}{ Recruitment } & Internal & Promotion-transfer & 2.851 & 0.005 \\
\hline & & External & Walk-ins & 3.226 & 0.002 \\
\hline & \multirow{5}{*}{ Selection } & Employment Test & Personality test & 2.909 & 0.005 \\
\hline & & \multirow{3}{*}{$\begin{array}{l}\text { Employment } \\
\text { Interview }\end{array}$} & Group & 2.852 & 0.005 \\
\hline & & & Non-Structured & 2.703 & 0.008 \\
\hline & & & Past experiences & 2.641 & 0.010 \\
\hline & & Decision Maker & $\begin{array}{l}\text { Immediate supervisors } \\
\text { with HRM manager }\end{array}$ & 3.725 & 0.0001 \\
\hline & \multirow{2}{*}{ Training } & Informational & Audiovisual & 4.931 & 0.0001 \\
\hline & & Experimental & On-the-job & 2.295 & 0.024 \\
\hline & Payment & $\begin{array}{c}\text { Pay for } \\
\text { Performance }\end{array}$ & Variable & 6.210 & 0.0001 \\
\hline & \multirow{3}{*}{ Reward } & Financial & Gain sharing bonus & 4.261 & 0.0001 \\
\hline & & Non-Financial & Training pay & 2.672 & 0.009 \\
\hline & & Flexible & Cafeteria & -7.949 & 0.0001 \\
\hline & \multirow{2}{*}{$\begin{array}{c}\text { Performance } \\
\text { appraisal }\end{array}$} & Kind & Immediate supervisor & 4.261 & 0.0001 \\
\hline & & Method & Results-oriented & 4.879 & 0.0001 \\
\hline & Work Relation & Bargaining & Collective bargaining & 2.600 & 0.011 \\
\hline
\end{tabular}

Table 4. Summary of indexes for the structural equation model

\begin{tabular}{|c|c|c|c|}
\hline & Value index in model & Standard index & Result \\
\hline & 1.101 & $2<$ & Goodness of fit \\
\hline & 0.111 & $>0.05$ & Goodness of fit \\
\hline & 0.034 & $>0.05$ & Goodness of fit \\
\hline & 0.984 & $0.9>$ & Goodness of fit \\
\hline & 0.988 & $0.9>$ & Goodness of fit \\
\hline & 0.779 & $0.05>$ & Goodness of fit \\
\hline & 0.697 & $0.05>$ & Goodness of fit \\
\hline
\end{tabular}

Table 5. The results obtained from combined effect of CT's TV and TA through crossover regression test on sub-HRMS

\begin{tabular}{|c|c|c|c|c|c|}
\hline TV and TA effect on & \multicolumn{2}{|c|}{ Coefficient } & Std. Error & t-Statistic & Prob. \\
\hline \multirow{3}{*}{ Recruitment } & $\mathrm{C}$ & 2.335 & 0.190 & 12.229 & 0.0001 \\
\hline & TV\&TA & 0.071 & 0.014 & 4.952 & 0.0001 \\
\hline & \multicolumn{3}{|c|}{$\mathrm{R}^{2}=0.378$} & \multicolumn{2}{|c|}{ D.W $=2.022$} \\
\hline \multirow{3}{*}{ Selection } & $\mathrm{C}$ & 1.951 & 0.176 & 11.050 & 0.0001 \\
\hline & TV\&TA & 0.092 & 0.013 & 6.681 & 0.0001 \\
\hline & \multicolumn{3}{|c|}{$\mathrm{R}^{2}=0.548$} & \multicolumn{2}{|c|}{ D.W $=1.817$} \\
\hline \multirow{3}{*}{ Training } & $\mathrm{C}$ & 1.663 & 0.166 & 9.995 & 0.0001 \\
\hline & TV\&TA & 0.124 & 0.012 & 9.867 & 0.0001 \\
\hline & \multicolumn{3}{|c|}{$\mathrm{R}^{2}=0.663$} & \multicolumn{2}{|c|}{ D.W $=1.872$} \\
\hline \multirow{3}{*}{ Payment } & $\mathrm{C}$ & 1.971 & 0.166 & 11.827 & 0.0001 \\
\hline & TV\&TA & 0.135 & 0.011 & 11.765 & 0.0001 \\
\hline & \multicolumn{3}{|c|}{$\mathrm{R}^{2}=0.646$} & \multicolumn{2}{|c|}{ D. $W=1.987$} \\
\hline \multirow{3}{*}{ Reward } & $\mathrm{C}$ & 2.218 & 0.223 & 9.933 & 0.0001 \\
\hline & TV\&TA & 0.062 & 0.015 & 3.929 & 0.0001 \\
\hline & \multicolumn{3}{|c|}{$\mathrm{R}^{2}=0.221$} & \multicolumn{2}{|c|}{ D.W $=1.831$} \\
\hline \multirow{3}{*}{ Performance appraisal } & $\mathrm{C}$ & 1.903 & 0.171 & 11.115 & 0.0001 \\
\hline & TV\&TA & 0.113 & 0.012 & 9.150 & 0.0001 \\
\hline & \multicolumn{3}{|c|}{$\mathrm{R}^{2}=0.580$} & \multicolumn{2}{|c|}{ D.W $=1.857$} \\
\hline \multirow{3}{*}{ Work Relation } & $\mathrm{C}$ & 2.204 & 0.173 & 12.698 & 0.0001 \\
\hline & TV\&TA & 0.097 & 0.011 & 8.180 & 0.0001 \\
\hline & \multicolumn{3}{|c|}{$\mathrm{R}^{2}=0.504$} & \multicolumn{2}{|c|}{ D.W $=2.064$} \\
\hline
\end{tabular}




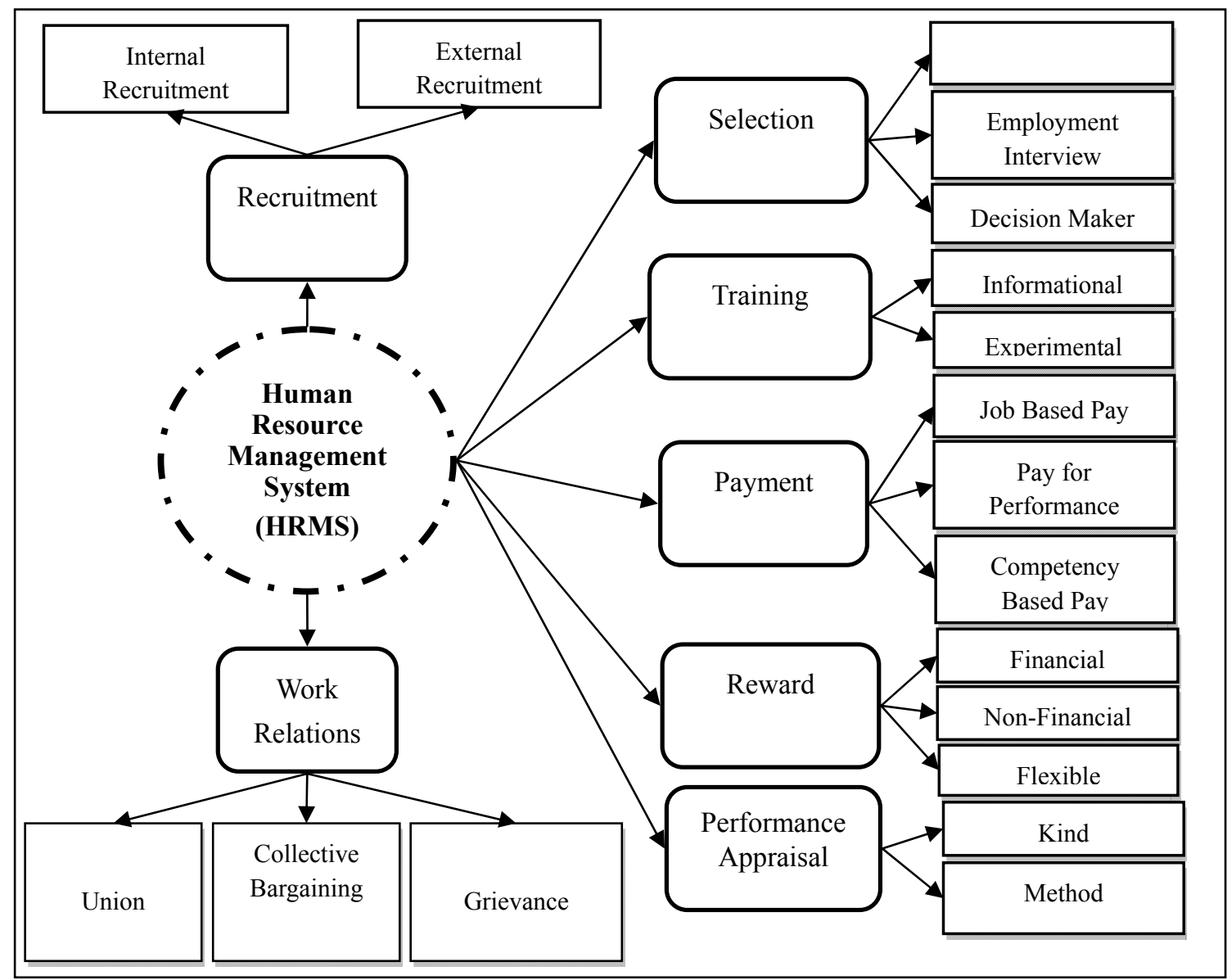

Figure 1. Human Resource Management System (HRMS) Model

\begin{tabular}{|c|c|c|c|}
\hline \multirow{4}{*}{$\begin{array}{c}\text { Variability } \\
\text { Low }\end{array}$} & \multicolumn{2}{|c|}{ Analyzability High } & \multirow{4}{*}{$\begin{array}{c}\text { Variability } \\
\text { High }\end{array}$} \\
\hline & $\begin{array}{c}\text { Routine } \\
\text { Technology }\end{array}$ & $\begin{array}{l}\text { Engineering } \\
\text { Technology }\end{array}$ & \\
\hline & $\begin{array}{c}\text { Craft } \\
\text { Technology }\end{array}$ & $\begin{array}{l}\text { Non-Routine } \\
\text { Technology }\end{array}$ & \\
\hline & \multicolumn{2}{|c|}{ Analyzability Low } & \\
\hline
\end{tabular}

Figure 2. Typology of CT according to Perrow 


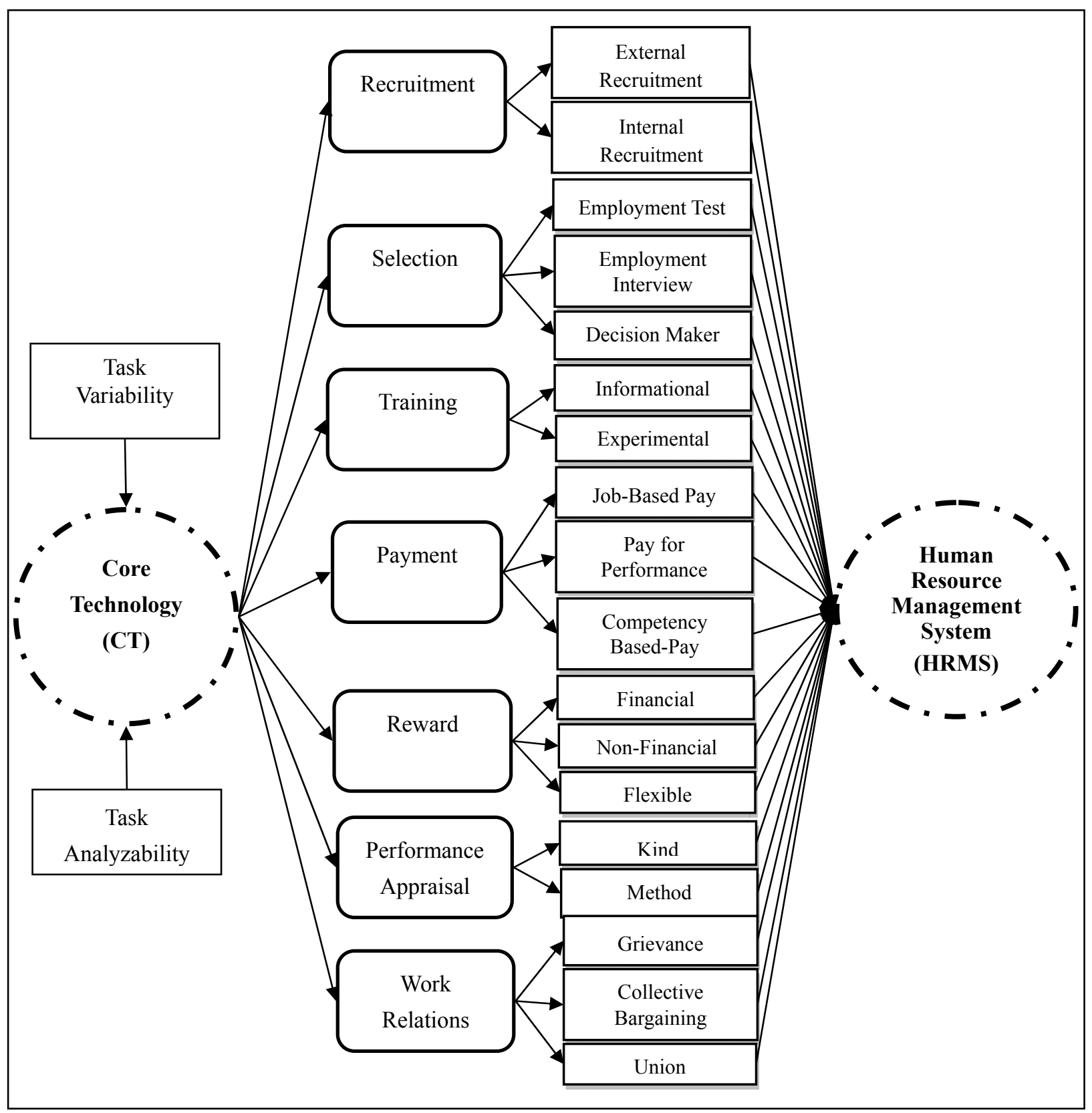

Figure 3. The conceptual framework of the study 


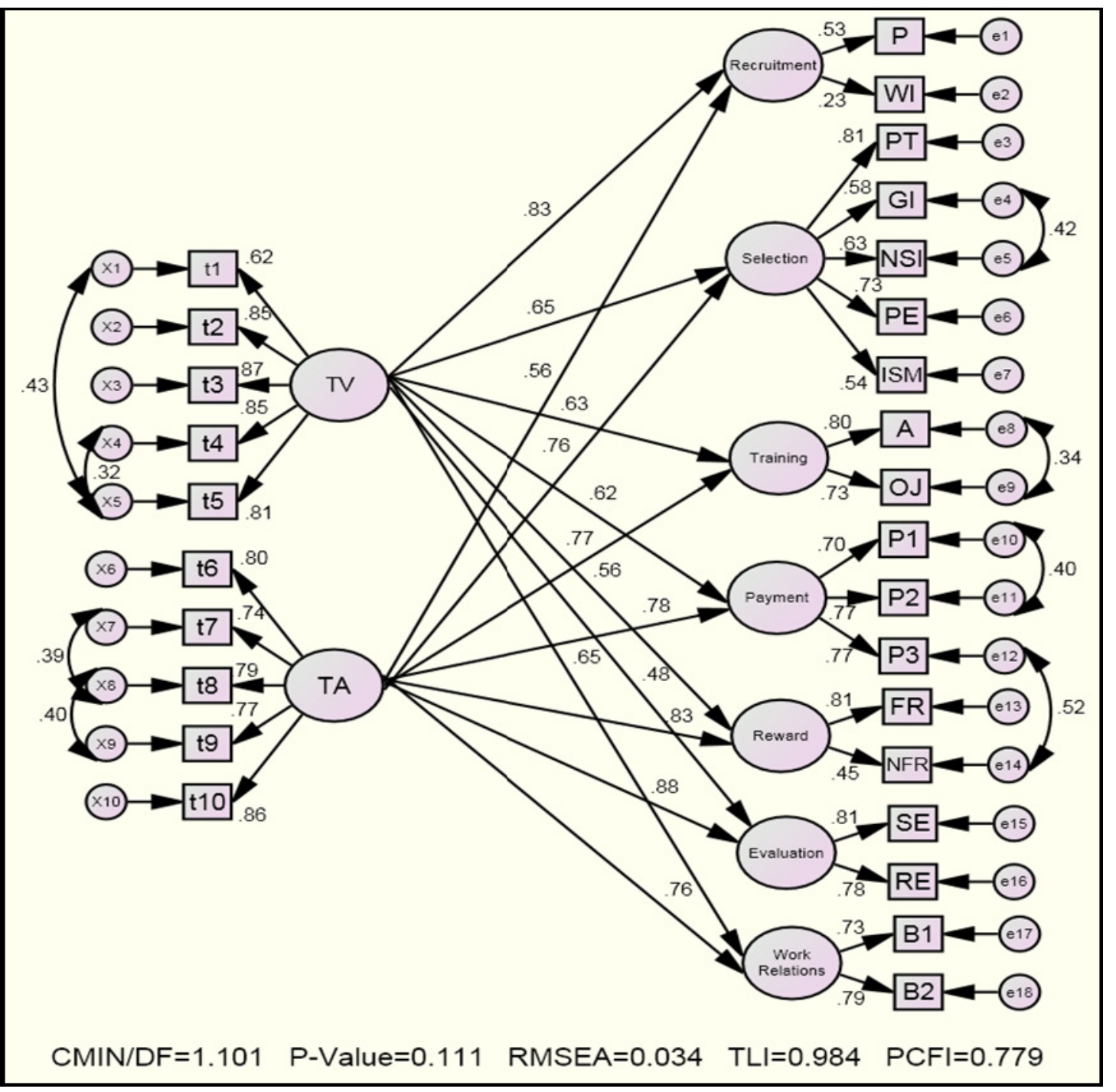

Figure 4. The pattern of CT's structural equation's effect on HRMS

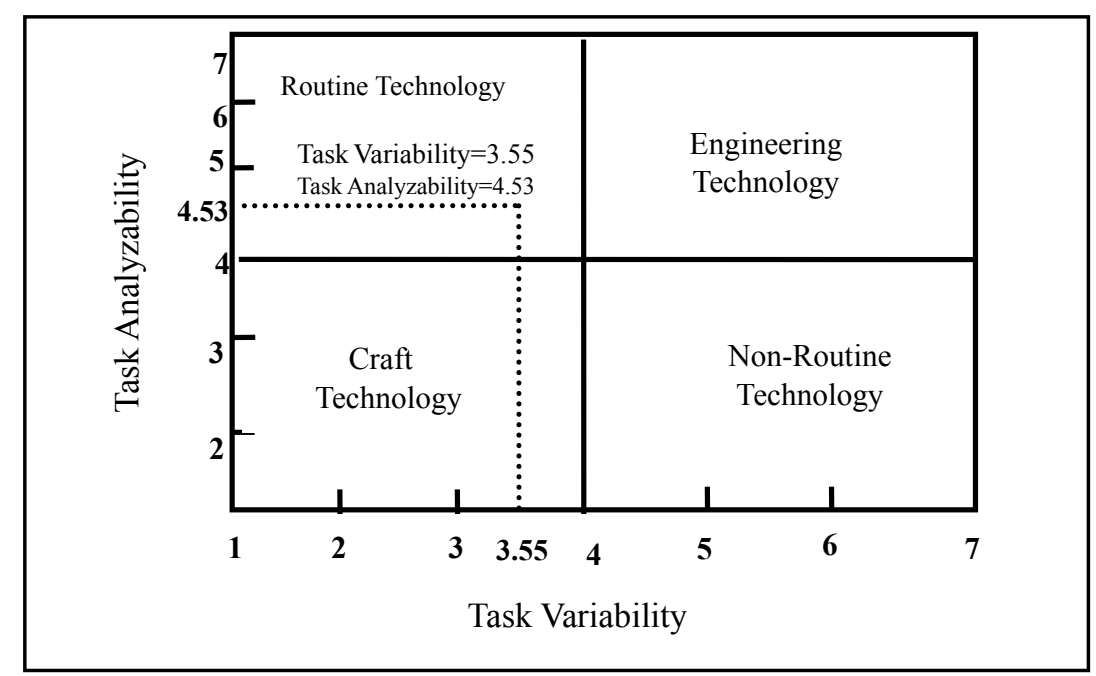

Figure 5. Determining the type of CT in automobile manufacturing plants according to Perrow's typology 


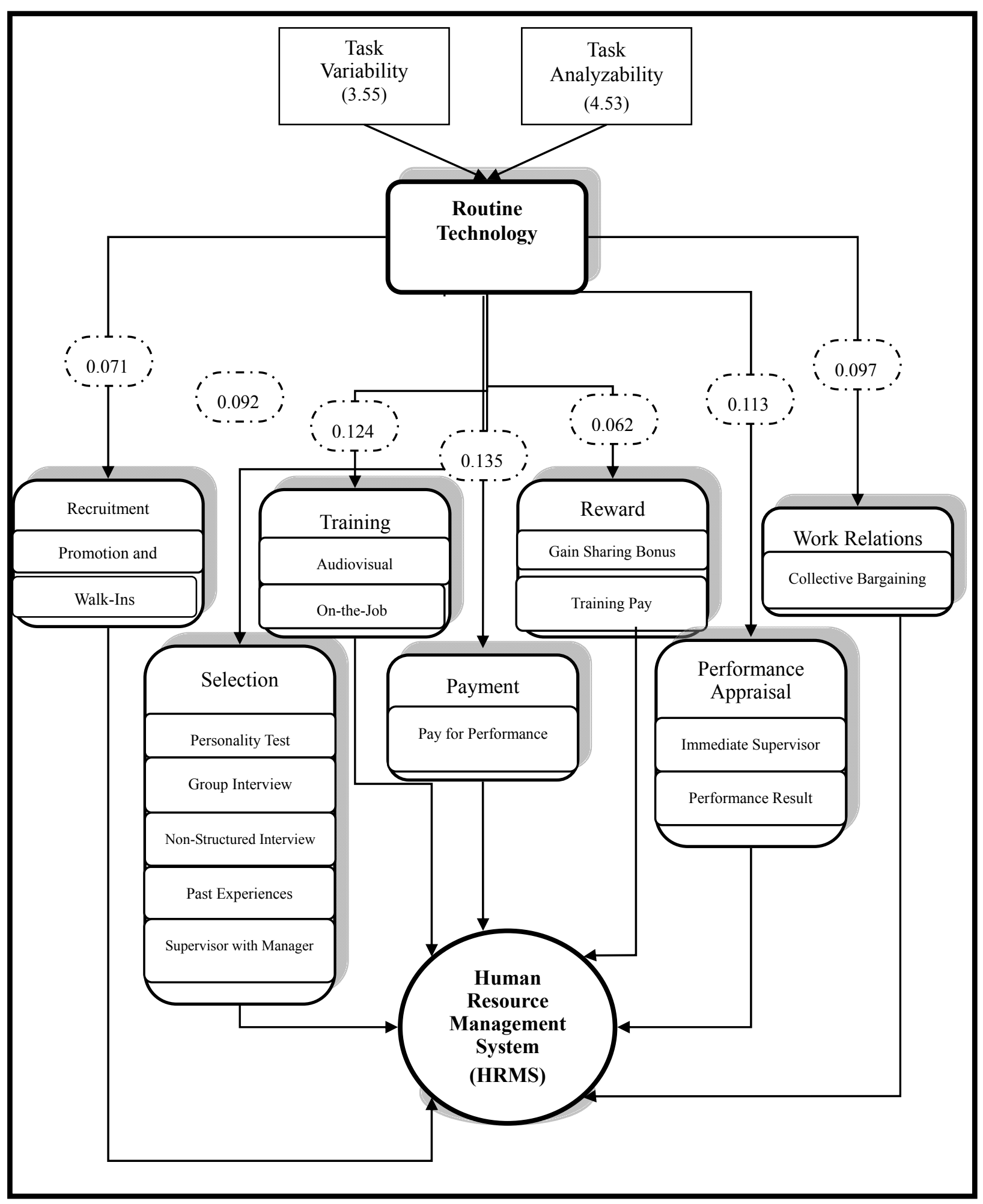

Figure 6. The model of CT effect on HRMS in automobile industry of Iran 